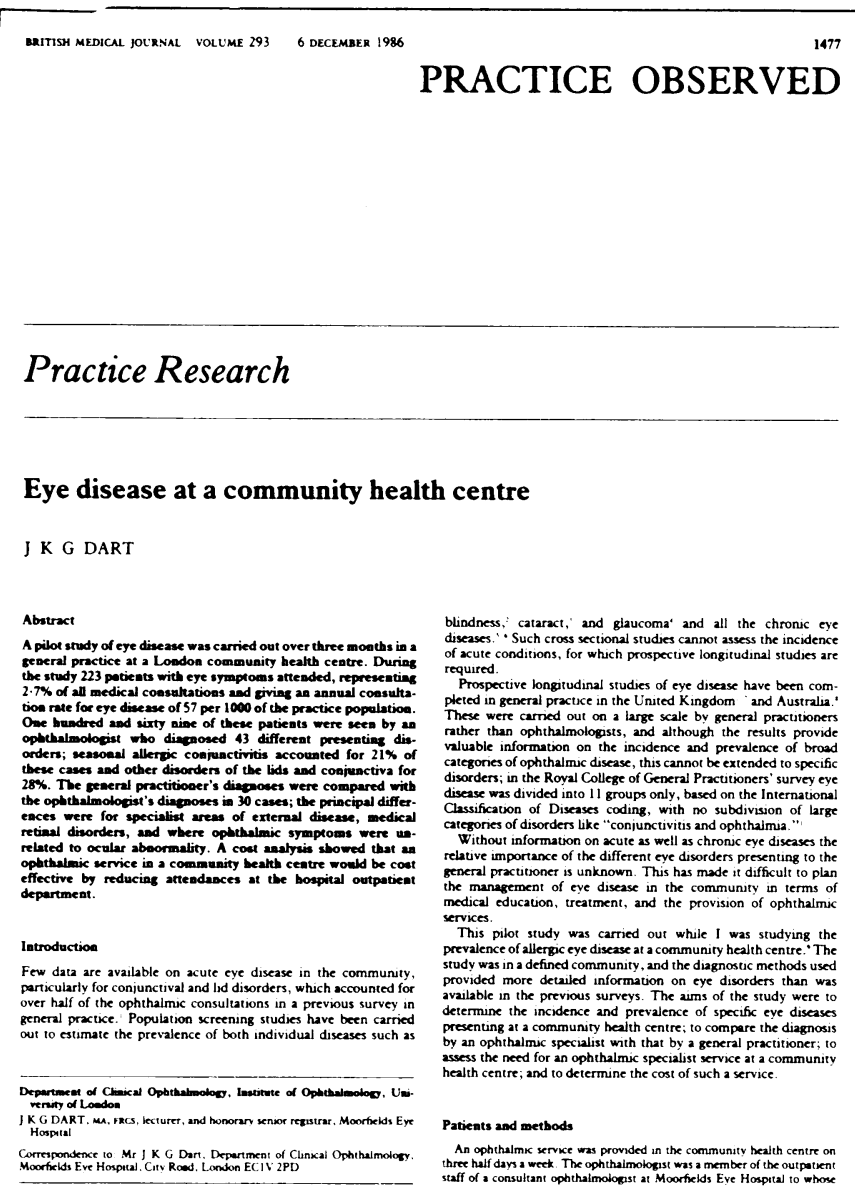
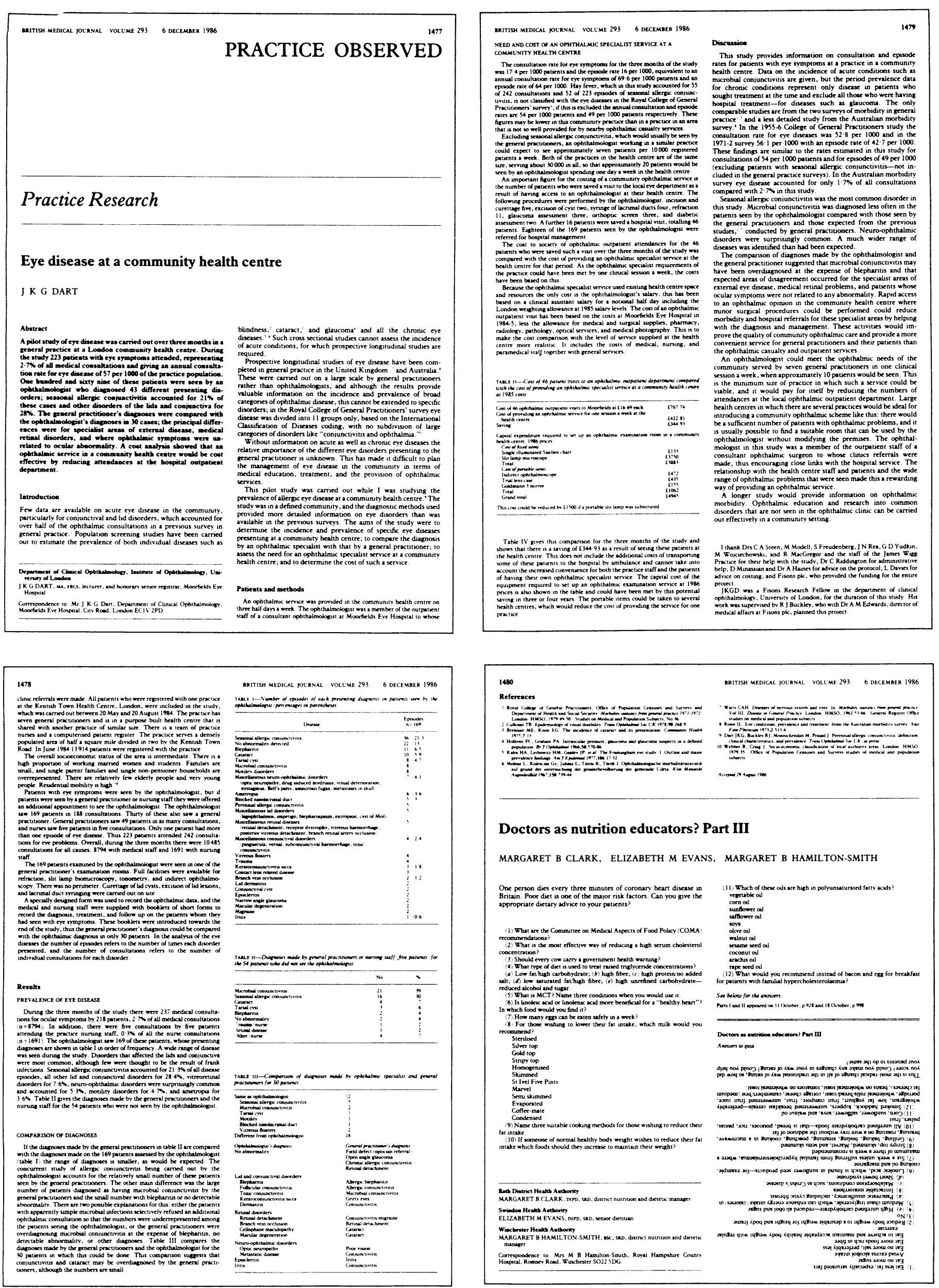

\title{
Doctors as nutrition educators? Part III
}

MARGARET B CLARK, ELIZABETH M EVANS, MARGARET B HAMILTON-SMITH

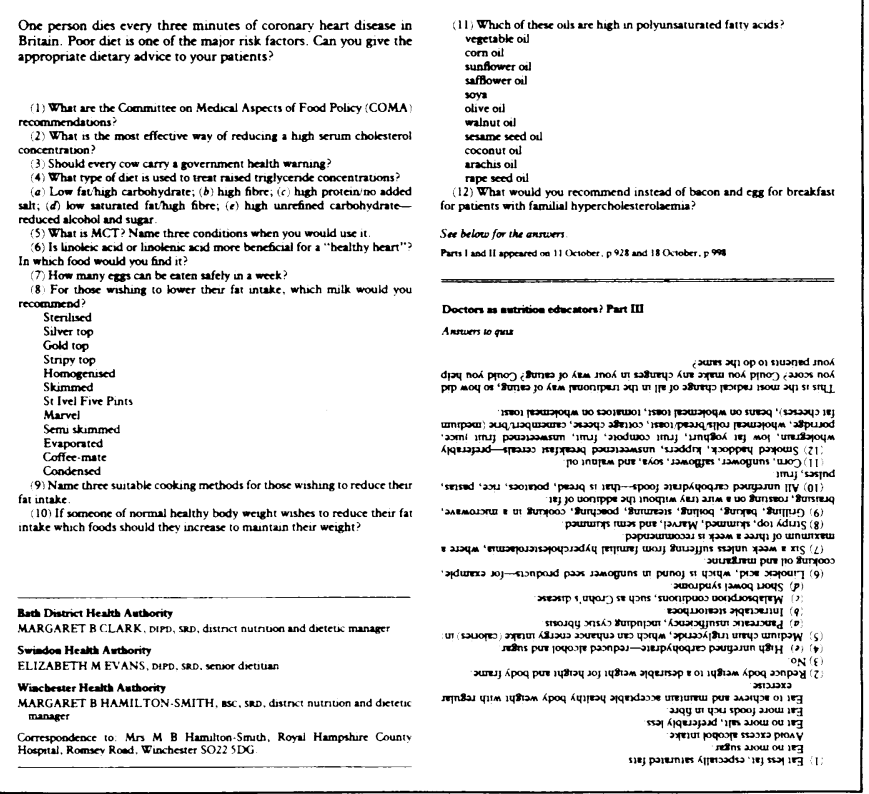

